\title{
On the record...
}

\section{Interview with Judge Deon van Zyl, Inspecting Judge, Judicial Inspectorate of Prisons}

\begin{abstract}
In October the Judicial Inspectorate of Prisons (JIOP) released its annual report for 2008/9. ${ }^{1}$ In this interview the Inspecting Judge, Deon Van Zyl, spoke to Chandré Gould about the report and about key problems identified by the JIOP.
\end{abstract}

Chandré Gould (CG): Many of the problems identified in the JIOP's annual reports over the past five years at least remain consistent, year in and year out. How will the JIOP hold the DCS and other relevant departments accountable for attending to the problems identified and implementing the recommendations?

Judge Deon van Zyl (DvZ): Well the moment you say 'hold accountable' I have to react and say that there is no way we can hold them responsible because that is not our mandate. We would hope that they would react because they would like to receive a more positive report the next year. But we cannot hold them responsible.

CG: Isn't that a problem?

DvZ: Well, to an extent it is. As a judge you can make a ruling in a case; but our mandate is quite circumscribed by the Act. We can report on Correctional Centres and on the treatment of inmates and anything related to that, but we cannot require a particular response. We report to the Minister and to the Parliamentary Portfolio Committee on Correctional Services and we will bring the report to the attention of the Deputy Minister and to provincial MECs, but it is up to them to act.

CG: One of the problems seems to be that recommendations made by the JIOP are not acted on; and even legal requirements (e.g. for prisons to report segregation and solitary confinement) are not adhered to. What are you going to do about this?
DvZ: Well, once again the best we can do is report this. As things presently stand we do usually get an immediate reaction. The head of a centre does not want to be investigated by his head office and therefore they tend to react quickly when we bring a matter to their attention. I have experienced very few problems in this regard.

CG: The JIOP and the Independent Prison Visitors (IPVs) visit prisons, but there are no published minimum standards against which conditions in correctional centres can be measured. For example when visiting a prison, how do the IPVs or the JIOP determine whether a health care system is good or bad - are there set standards against which this can be measured?

DvZ: We have certain benchmarks against which conditions in correctional centres are measured, most noticeably the Correctional Services Act 111 of 1998, the Regulations and the White Paper. IPVs are given these benchmarks when they are appointed, and they report against them. We do get a good idea from their reports about the conditions in specific centres. There are 237 operational correctional centres and we deal with a large number of reports. Generally though, I believe that we have a good idea of what is going on and we report that to the Minister.

We do find that conditions vary tremendously between prisons. 
CG: Is this because of variable competence of heads of prisons?

DvZ: It has more to do with resources and the extent to which money is being spent on a particular centre. For example, prisons are reliant on the Department of Public Works to come and do repairs. Sometimes prisons have to wait months or even years before the Department of Public Works responds. In that situation the heads of centres may be excellent but there is little they can do. They can't compel the Department of Public Works to act.

In our report we do point out which centres function well, and why, and readers can draw comparisons from that. Of course the human element always plays a role, but it is not the only thing that affects the quality of a centre. We try to distinguish between centre-specific problems which are experienced at some correctional centres, and so-called systemic problems such as lack of rehabilitation programmes, work opportunities, shortage of staff, etc. which are problems being experienced at almost every correctional centre in the country.

CG: How will the JIOP use its existing and expanded mandate to stop torture in prisons?

DvZ: When you speak of torture it is something that is very clearly defined in international law (in the Convention Against Torture and Other Cruel Inhuman or Degrading Treatment or Punishment and the Optional Protocol to the Convention against Torture). In my experience over the past 18 months I have not encountered anything that could be defined as torture. I haven't been persuaded that there is a problem of torture in South African prisons. Of course there may be incidents that are not brought to our attention, but I don't believe that this is a problem at this stage. It may be that conditions under which inmates are held could amount to torture, but even in this case I have no reason to believe that conditions are so bad at any of our prisons.

CG: How do you see your role in investigating and reporting on corruption?
DvZ: Well before the previous amendment to the Act, the whole question of corruption in the Department of Correctional Services was something to which the JIOP had reference. Just before the Jali Commission of Inquiry Judge Fagan (the then Inspecting Judge) was requested to look into the problem of corruption. As it is now the Act only indirectly refers to corruption and we don't see the investigation of corruption as our role, unless there is a direct link between corruption and the treatment of inmates.

CG: You refer in the introduction to the Annual Report to the fact that the large number of Awaiting Trial Detainees (ATDs) is the greatest contributor to overcrowding. You say that many of these ATDs are people who are remanded in custody on the basis that the police are supposedly undertaking investigation into their role in a crime. Yet, you say that 'in a substantial number of cases the person is later released because there is not sufficient evidence of their involvement in the crime'. This is something that clearly needs to be addressed, but the responsible authority would be the police. What will you be doing about this problem?

DvZ: I think that the way in which arrests are being carried out leaves much to be desired. The Criminal Procedure Act only allows for a person's freedom to be curtailed through incarceration if there is a reasonable suspicion that he or she has been involved in a crime. As it is now people are being arrested left, right and centre because they are in the vicinity of a crime; then a long and drawn out investigation ensues. In many cases people are being arrested when there is not proper justification for the arrest. This is very serious. The right to freedom is a constitutional right and the curtailment of freedom should be a measure of last resort.

The problem is that at the present stage police performance is generally measured by the number of arrests that are made, whereas the Department of Justice (DoJ) measures success by the number of convictions achieved. There is a huge difference between these two approaches. Only a tiny percentage of arrests (I mean single 
digit) eventually result in conviction and this is not being properly addressed. The DCS can't do anything about this, but the Department of Justice can.

When someone is arrested they have to appear before a magistrate within 48 hours of being arrested. It is the magistrate's job to determine whether there are good reasons for the person having been arrested in the first place. This is not happening. Now the prosecutors (who are also officials of the DoJ) ask for a postponement at the first appearance on the basis of the need for further investigation. I'm not convinced that the prosecutors are checking whether the investigations are actually taking place and whether they are making any progress. The investigating officer (a police member) should satisfy the prosecutor that there is an investigation under way and that it is making progress. The prosecutor must in turn convince the magistrate of this. If a postponement is then granted it is essential, at the resumed hearing, that the test should be applied even more stringently. Yet in practice there are multiple postponements, and I am not convinced that either the prosecutors or magistrates are ensuring that there is progress in the investigations.

This is even worse when there are children involved. I was recently at Grootvlei prison in Bloemfontein where there were 14 and 15 yearolds who had been in detention for up to a year while investigations were apparently going on. This is in direct conflict with a child's right, in terms of section 28(1)(g) of the Constitution, not to be detained except as a measure of last resort and then only for the shortest appropriate period of time. The only basis on which continued incarceration should be permitted is where there is strong prima facie evidence that the child was involved in a crime and there is evidence of progress in the investigation.

This is a huge part of the ATD problem. I believe that the ATD population can be reduced by 50 per cent if proper procedures are followed. That is why the relevant cluster (DCS, Police and DoJ) must direct its attention unequivocally to making progress. The cluster meets regularly but it seems that much time is spent on discussion and too little on action.

Members of the Judicial Inspectorate regularly attend High Court and Lower Court case management meetings but these are not always useful or productive. In my respectful view there is not sufficient achieved at these meetings, which are frequently time-consuming and expensive. But they are not as expensive as keeping detainees in prisons. Bear in mind that it costs about R70 000 to keep a detainee incarcerated for a year. If they are detained for a year or more and then released, there will necessarily be a huge waste of taxpayer's money.

Section 105A of the Criminal Procedure Act makes provision for plea bargaining and alternative sentences, especially in cases of lesser offences, e.g. first time offences and petty offences. Such offenders should not be incarcerated. If they are prepared to plead guilty they could, for example, be sentenced to community corrections or victim compensation, in which event they would be enabled to make amends to the community for the offences they have committed. This is the essence of restorative, as opposed to retributive, justice. I am not sure that judicial officers are considering pleabargaining sufficiently. Until they do so they will generally impose custodial sentences rather than alternatives and the problem of overcrowded prisons will continue.

I've been in contact with the Minister and Deputy Minister of the DCS, and also with the Deputy Minister of Justice, about these matters. I hope also, in the course of time, to exchange ideas with the Minister of Justice and the Minister of Police. Such meetings can be extremely informative and useful.

CG: You also refer in the Annual Report to the fact that there has been a marked increase in the number of inmates serving sentences in excess of five years (from 49 per cent in 1998 to 67 per cent in 2009) and a growth of 1023 per cent in inmates serving life sentences. You suggest that 
there is a need to develop accurate forecast models. Yet it seems as though the root of this problem is the minimum sentencing legislation?

DvZ: Absolutely. The forecast is meant to deal with the huge influx of long-term inmates. But, there should not have been such a huge increase of inmates with long sentences in the first place. The legislative determination of the length of a sentence is, in my respectful view, totally unacceptable. Numerous calls have been made, by judges and other lawyers, for the repeal of the minimum sentence legislation, but unfortunately it still continues and with it the increasing number of long-term detainees.

Judges who have heard all the evidence in a case are, generally speaking, in the best position to apply their discretion and to decide on an appropriate sentence. The statutory determination of minimum sentences must of necessity interfere with the exercise of judicial discretion, which constitutes one of the most important functions of a judge. It is quite correct that different judges may impose different sentences. If, however, the sentence should be regarded as inappropriate, there are a number of safeguards, in the form of appeals at various levels, for reconsideration of such sentence.

Not only has minimum sentence legislation given rise to a huge increase in the number of offenders serving long-term sentences, but it has also served a retributive rather than a restorative purpose. This is not in line with the principles enunciated in the White Paper on Corrections of 2005, which focuses on rehabilitation and reintegration on the basis of restorative justice. I would like to see the minimum sentence legislation struck from the statute books and an unfettered discretion returned to the judiciary in regard to the sentencing process.

CG: You have noted that there were 982 so-called natural deaths in custody during 2008/9 - that is a lot of people who are dying in prison when in theory they should have been allowed to die at home on medical parole. This matter was of course recently brought to the public's attention when Shabir Shaik was released from prison on medical parole. What is the position of the JIOP?

DvZ: We have made a recommendation

suggesting that the definition of who qualifies for medical parole should be revisited. It is very difficult, if not impossible, for anyone, even an experienced medical doctor, to determine when someone is in the final stage of a terminal illness. I've seen over and over again people in prison who are so ill that they are unlikely to recover. By that stage they are shivering, unable to get out of bed and not responding to questions. There may, of course, be reasons other than the existing legislation for the continued detention of seriously ill inmates until they die. One of these is that families often can't afford to take them in and care for them. Not all cases are like the Shabir Shaik or Colin Stanfield cases where their families could take them in and provide them with firstclass care.

One factor which should, in my view, be considered in redefining the requirements for medical parole, is the constitutionally protected dignity of the inmate. I have been given to understand that the National Commission for Correctional Services (NCCS) has requested Judge Ian Farlam to investigate and report on the revision of requirements for medical parole. I have no doubt that this, and other, issues will be adequately addressed.

CG: On the face of it, the recommendation that you make in the Annual Report regarding changing of floor space norms in order to reduce overcrowding, seems to offer a neat solution, especially to DCS. Yet, it is based on the assumption that inmates are no longer merely being warehoused, and held in their cells most of the time. There is little indication at this stage that the DCS can actually deliver on the White Paper's rehabilitation requirements - that being the case do you think that given the current realities this solution can actually work without further prejudicing inmates?

DvZ: Well look, if inmates are going to spend 23 hours in their cells, our recommendation to 
revisit the floor space norms won't work. But inmates should be given fresh air and should be able to work outside during the day. Cells should just be for sleeping in, and if that is the case you don't need much space in which to place a bed. This suggestion will, however, only work if DCS introduces a system of working during the day. Working, not hard labour of course, will provide inmates with exercise and fresh air. It will keep them busy, help to make them fit and they could even be paid for their work. In addition, it could assist in developing their skills, by which they would be able to reintegrate more easily into society on release.

CG: So, if this is such a good solution why is it not being done?

DvZ: I am of the view that too much emphasis is being placed on security and on preventing escapes at the cost of allowing inmates to work and participate in programmes. And although DCS achieved excellent results with their strategy to reduce escapes we have now reached a point of diminishing returns. To continue with the spending of millions of rands to reduce escapes by such small margins such as one per 10000 is wasteful. Such money should rather be used to build workshops, classrooms, etc. We believe that offenders should be working to improve the centres where they are incarcerated. This would also be in line with the DCS's statutory duty to move towards self-sufficiency.

I have raised this in discussions with the Chair of the Parliamentary Portfolio Committee on Correctional Services, Mr Vincent Smith, and also with the Minister and Deputy Minister of Correctional Services. They all appear to be positively disposed to the idea, but agree that there is a lot of work to be done before it can become a reality.

CG: Finally, is there anything else that you would like to bring to the attention of SACQ readers?

DvZ: In the Annual Report ${ }^{2}$ we speak about the problem relating to how deaths in prisons are classified - either as natural or unnatural. There are currently far too many deaths in correctional centres. The question is why? The Correctional Services Act as amended does not define 'natural' or 'unnatural' deaths. Heads of Correctional Centres regard all deaths by natural causes (i.e. those which are not caused, for example, by violent assaults or murders) as natural deaths. But this does not cover the case where a seriously ill person does not receive the required or prescribed medication and consequently dies. This should not, in my view, be classified as a natural death. There should be a physical examination of all persons admitted to correctional centres and, where necessary, they should be given the medication they require. We would therefore, like to see that every death in a correctional centre should be investigated and be subject to a post mortem examination and an inquest.

\section{CG: Who would do such an investigation?}

DvZ: The DCS should ensure that proper independent investigations take place and statutory provision should be made for such cases. We are directing attention to this problem in the Annual Report.

\section{NOTES}

1 The Inspecting Judge of Prisons, Judge Deon Hurter van Zyl, Annual Report for the Period 1 April 2008 31 March 2009, Cape Town: Judicial Inspectorate of Prisons, 2009.

2 Ibid, 24. 